\title{
The Effect of Project Based E-Learning Models Toward Learning Outcomes and Critical Thinking Skills of Vocational High School Students
}

\author{
Made Delina Rusnawati, I Wayan Santyasa, I Made Tegeh \\ Universitas Pendidikan Ganesha \\ delinarusnawati99@gmail.com
}

\begin{abstract}
Learning outcomes and critical thinking skills are main competencies that students must achieve in Digital Simulation subjects. This study aimed to describe the differences in learning outcomes and critical thinking skills together between students who learned by using project-based e-learning model and students who learned by using direct e-learning in Digital Simulation subjects. This research used quasi experiment method. The research design used was a pretest-posttest control group design. The research sample consisted of 4 classes or 133 students by using a simple random sampling technique. This study used two test instruments namely, the learning outcomes test in the form of objective tests and the critical thinking skills test in the form of essay test. Data were analyzed descriptively and Multivariate Analysis of Covariate (Mancova) with hypothesis testing using a significance level of 0.05 . The findings showed that first, there were differences in learning outcomes and critical thinking skills simultaneously between students who learned by using a project-based e-learning model and students who learned by direct e-learning model. Second, there was no difference in learning outcomes between students who learned by using the project-based elearning model and students who learn by direct e-learning model. Third, there were differences in critical thinking skills between students who learned by using the project-based e-learning model and students who learned by using direct e-learning model.
\end{abstract}

Keywords: learning outcomes, critical thinking skills, project-based e-learning, direct elearning, digital simulation.

The development of education in the world cannot be separated from the development of the industrial revolution that occurred in the world. The era of the industrial revolution 4.0 that we currently face in the 21 st century requires that a teacher is able to change the mindset about learning outcomes. A teacher must be able to achieve the learning goals in the 21st century, namely with minimum 4C criteria (critical thinking, creative thinking, collaboration, and communicative). The development of science in the 21 st century requires individuals to become quality human resources. One of the characteristics of quality human resources is being able to manage, use, and develop the power of thinking, one of which is critical thinking. Critical thinking skills at this time are needed, so that children in the future when receiving information do not immediately believe it, are not easily influenced and always check the truth of the information obtained. According to Rahyu and Hidayat (2017) one of the criteria that must be possessed by the 21 st century generation is the ability to think critically. Critical thinking is a systematic process that allows students to formulate and evaluate their own beliefs and opinions. Hashemi (2011) also believes that through critical thinking activities can improve students' thinking skills so that they can assist in the learning process of students. In critical thinking activities, students are required to complete the task as well as possible and find relevant information to help in completing the task.

In the current era of globalization, a lot of technology can be used to support the learning process in schools, one of which is the internet. The internet is one of the communication media in order to add learning experiences for students to be actively involved in learning activities. In addition to the internet, the use of other information technology can be in the form of computer devices and smartphones. One effort that can be done by teachers to improve student competency is by applying a project-based elearning learning model. This learning model is one of the recommended models to be applied in learning in the 2013 curriculum which requires 
students to be more active in the learning process. The project-based learning model is also able to invite students to play an active role in the learning process so that it is expected to increase the ability of students themselves. The PjBL model is a learning model using real projects in life that are based on high motivation, tasks and problems to form mastery of competencies which are carried out jointly in Barel's problem solving efforts (2000). The aim of the project-based model is the achievement of high-level thinking skills needed in the 21 st century. This is consistent with the opinion of Yeni and Ruhimat (2018) which states that a number of skills that students need to develop to face the challenges of the 21 st century are creative and innovative, critical thinking, communication and collaboration. The Ministry of Education and Culture (2013) also states that project-based learning is a learning method that uses problems as a first step in gathering and integrating new knowledge based on experience in actual activities. Project based learning is a student-centered learning model for conducting an in-depth investigation of a topic. Based on this theory, it can be concluded that project-based learning integrated with e-learning media is learning that focuses on student activities to be able to understand a concept by conducting an indepth investigation of a problem and finding a solution by making a project. The reasons why the project-based learning model is used as follows. (1) increase students' motivation in developing projects, (2) more active learning opportunities for students, (3) increase critical thinking skills and (4) students have responsibility for learning. Project based e-learning also offers ease of learning by delivering learning content online that allows it to be accessed by students flexibly. Project based e-learning is oriented towards learning outcomes with reference to learning activities undertaken by students. In other words, project-based e-learning facilitates students to learn in a way that is considered easy to achieve learning objectives.

Based on research by Jamilla and Lazulva (2020), the project-based learning model assisted by Google classroom provides better learning outcomes in the cognitive domain. The ability to understand the chemistry concepts of students who learn with the project-based learning model assisted by Google classroom using video learning is better than the lecture learning method. In this study revealed several obstacles including not implementing a project learning model, besides the lack of use of media, especially electronic media that utilize internet access and lack of student discipline in terms of learning, so the need for the application of innovative learning models so that students can get more learning outcomes well. Furthermore, research (Niswara et al., 2019) states that the application of project-based learning models assisted by puzzle media has an influence on students' high order thinking skills. This is evidenced from the more interactive students in the learning process and students are able to create good learning conditions and situations by using a project-based learning model assisted by puzzle media. As for some of the obstacles revealed in this study are the creativity of students who must get a good assessment that not only relies on the final assessment but also the assessment of the learning process itself so that students' high-level thinking skills can be created properly. This study was also similarly disclosed by (Na'imah et al., 2015) he said from the results of his research showed the feasibility of applying project-based learning models assisted by elearning to improve student learning outcomes both psychomotor, affective and cognitive assessment of students. This is evidenced from the increase in students' activeness during the learning process and increased motivation in learning. In addition, students feel that the existence of project-based learning assisted by e-learning can improve their skills in working together in groups, innovating in creating something new, utilizing existing learning resources and useful technology in the world of education. (Santyasa et al., 2020) also revealed in his research that there were significant differences in academic achievement between students studying in the PjBL and DI models. Which higher academic achievement is achieved by students studying with the PjBL model. The obstacle revealed in this study is that there are significant differences in academic achievement between students who have high academic procrastination (HAP) and low academic procrastination (LAP). Higher learning achievement is achieved by students who have PAP. And the final results of this study reveal that there is an interactive effect between learning models and academic procrastination on student academic achievement. Strong interactions occur at low procrastination for both learning models. From these studies prove the learning model has an impact on both learning achievement and student procrastination itself.

Based on several exposures, the results of previous studies show that learning outcomes and critical thinking skills of students can be improved through project-based learning models that are assisted by e-learning. So this research was 
conducted at Sawan State Vocational School with the aim of wanting to find out the differences in learning outcomes and critical thinking skills of students in the learning process using the PjBeL learning model of digital simulation subjects. This study uses a quasi-experimental research design with a basic pattern of pretest / posttest nonequivalent control group design.

\section{METHOD}

The research design used was a quasiexperimental research design with a basic pattern of pretest / posttest non-equivalent control group design. This design was chosen because it is not possible to control or manipulate all relevant variables. In this design sampling is done by selecting classes to be taken randomly. This design was chosen because during the experiment it was not possible to change the existing class. Provision of treatment is only done in the experimental class. For posttest observation / final observation will use an instrument in the form of objective tests for learning outcomes and a description for critical thinking skills.

The population of this study was all students of class $\mathrm{X}$ of the Hospitality Accommodation Department at Sawan State Vocational School 1 2019/2020 academic year consisting of classes X AP1, X AP2, XAP3, X AP4. All classes in the population do not have superior classes, meaning that the academic abilities of all students are homogeneously distributed. The number of class $\mathrm{X}$ students in Hospitality Accommodation at Sawan State Vocational School in 2019/2020 was 133 students. The sample consisted of 4 classes (67 experimental class students namely class X AP1 and $X$ AP3, while 66 control class students were XAP2 and XAP4. The study was conducted from April to May 2020. Topics of research material were digital citizenship ethics and search engine search techniques.

The independent variables in this study are project-based e-learning learning models for the experimental class and direct e-learning for the control class. Whereas the dependent variable is student learning outcomes and critical thinking skills. This study consisted of three stages of research, namely the preparation phase, the implementation phase and the final stage of the experiment.

The preparation phase of the experiment consists of preliminary observations, the preparation of learning tools and data collection instruments in the form of learning outcomes tests and tests of critical thinking skills: conducting validity of the contents of item analysis and internal consistency of items; and developing research schedules. The implementation phase of this experiment includes the implementation of a pretest to find out the results of early learning and critical thinking skills of students on digital simulation subjects; carry out learning by applying the learning model project-based e-learning experimental class and direct e-learning in the control class in accordance with the research schedule. The last stage of the experiment is to do a posttest to find out the student learning outcomes and students' final critical thinking skills in Digital Simulation subjects; analyzing test results; compile research reports.

The validity of the test items was tested by 2 experts who processed the data using Gregory's formula. The results of the validity of the learning outcomes test and critical thinking skills are 1 . Both types of tests have the reliability criteria of 0.765 for learning outcomes and 0.791 for critical thinking skills with a high category. Test item analysis was also carried out to justify the quality of test items, especially the item difficulty index (IKB) and item differential power index (IDB). After testing the instrument on learning achievement tests, it was found that 21 items of learning achievement tests met the standard with IKB $=0.30-0.70$ and met the IDB standard > 0.20 . For the critical thinking skills test of 20 items, only 1 item did not meet the IKB standard with a value of $<0.70$ and all other test items were declared to meet the IDB standard, which is $>0.20$. Meanwhile, for the internal consistency test items are used product moment correlation. All items of the learning outcomes test and the critical thinking skills test were declared consistent. For trials the Learning Outcomes are presented in Table 1 and Table 2 for critical thinking skills.

Table 1. Learning Outcomes Test Results

\begin{tabular}{clll}
\hline NO & $\mathrm{r}_{\text {(butir-total })} \geq 0.3$ & \multicolumn{1}{c}{ IKB $(0.30-0.70)$} & \multicolumn{1}{c}{ IDB $(>0.20)$} \\
\hline 1 & 0.326 & 0.448 & 0.2125 \\
4 & 0.392 & 0,610 & 0.2125 \\
6 & 0.321 & 0.488 & 0.2125 \\
7 & 0.334 & 0.500 & 0.2125 \\
8 & 0.333 & 0.500 & 0.2125 \\
11 & 0.463 & 0.610 & 0.2375 \\
12 & 0.321 & 0.463 & 0.2125 \\
13 & 0.379 & 0.683 & 0.2125 \\
14 & 0.399 & 0.451 & 0.2125 \\
15 & 0.409 & 0.427 & 0.2125 \\
16 & 0.354 & 0.268 & 0.2625 \\
18 & 0.384 & 0.512 & 0.225 \\
19 & 0.384 & 0.305 & 0.2125 \\
21 & 0.374 & 0.354 & 0.2625 \\
22 & 0.273 & 0.244 & 0.2375 \\
24 & 0.254 & 0.378 & 0.2125 \\
25 & 0.323 & 0.427 & 0.2125 \\
26 & 0.380 & 0.293 & 0.2125 \\
27 & 0.414 & 0.500 & 0.225 \\
29 & 0.368 & 0.415 & 0.2125 \\
\hline
\end{tabular}


Table 2. Critical Thinking Skill Test Results

\begin{tabular}{|c|c|c|c|}
\hline $\mathrm{NO}$ & $\begin{array}{c}r_{\text {(butir-total) }} \geq \\
0.3\end{array}$ & $\begin{array}{c}\text { IKB }(0.30- \\
0.70)\end{array}$ & $\begin{array}{c}\text { IDB } \\
(>0.20)\end{array}$ \\
\hline 1 & 1.041 & 0.63444 & 0.64583 \\
\hline 2 & 0.990 & 0.64539 & 0.625 \\
\hline 3 & 0.672 & 0.68181 & 0.63889 \\
\hline 7 & 1.105 & 0.63859 & 0.65972 \\
\hline 8 & 1.259 & 0.59832 & 0.71528 \\
\hline 9 & 1.154 & 0.64036 & 0.71528 \\
\hline 11 & 1.231 & 0.64539 & 0.71528 \\
\hline 16 & 1.092 & 0.6451 & 0.69444 \\
\hline 18 & 0.973 & 0.58589 & 0.625 \\
\hline 20 & 1.065 & 0.64451 & 0.65972 \\
\hline
\end{tabular}

Data collection was carried out through

(1) providing a pretest with 10 essay questions for critical thinking skills and 20 objective questions for learning outcomes; (2) implementing learning and (3) providing posttest. In this study the data analysis technique used is descriptive analysis and the hypothesis testing technique used is Multivariate Analysis of Covariance (Mancova). Analysis of covariance used is (1). data distribution normality test using Kolmogorov and Shapiro Wilk statistics; (2). homogeneity test for variance; (3). linearity test of student learning outcomes and critical thinking skills; (4) collinearity test.

\section{RESULTS AND DISCUSSION}

\section{Descriptive Analysis Results}

The results of the descriptive analysis involving 4 classes by dividing into 2 experimental classes using the 67 student $\mathrm{PjBeL}$ model, and 2 control classes using the direct elearning model of 66 students obtained analysis in the form of the mean and standard deviation of the pretest learning outcomes and thinking skills critical and posttest student learning outcomes and critical thinking skills are presented in Table 3.

Table 3. Average Results and Standard Deviation of Experiment and Control Classes

\begin{tabular}{lllll}
\hline & \multicolumn{2}{c}{ PjBeL } & \multicolumn{2}{c}{ Direct E-learning } \\
\hline & Pretest & $\begin{array}{c}\text { Posttes } \\
\mathrm{t}\end{array}$ & Pretest & $\begin{array}{c}\text { Posttes } \\
\mathrm{t}\end{array}$ \\
\hline Learning & $\mathrm{M}=$ & $\mathrm{M}=$ & $\mathrm{M}=$ & $\mathrm{M}=$ \\
outcome & 12.98 & 15.44 & 12.16 & 14.77 \\
$\mathrm{~s}$ & $\mathrm{SD}=$ & $\mathrm{SD}=$ & $\mathrm{SD}=$ & $\mathrm{SD}=$ \\
& 3.94 & 2.87 & 4.27 & 3.29 \\
\hline Critical & $\mathrm{M}=$ & $\mathrm{M}=$ & $\mathrm{M}=$ & $\mathrm{M}=$ \\
Thinking & 23.13 & 32.07 & 21.89 & 25.16 \\
Skills & $\mathrm{SD}=$ & $\mathrm{SD}=$ & $\mathrm{SD}=$ & $\mathrm{SD}=$ \\
& 4.57 & 2.89 & 3.85 & 3.59 \\
\hline
\end{tabular}

Based on Table 4 shows that the learning outcomes and critical thinking skills of students before and after treatment has increased.
Comparison of Mean Value of PjBeL \& Direct eLearning Model can be seen in Figure 1.

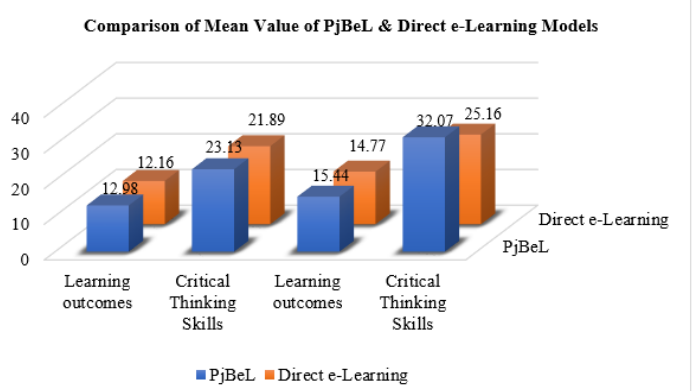

Figure 8.Comparison of Mean Value of PjBeL \& Direct e-Learning Models

The results of normality analysis of pretest and posttest data in 4 classes showed that the significance values obtained in the Kolmogorov-Smirnov and Shapiro-Wilks tests were more than $\alpha$ (researchers used $\alpha 0.05$ ). Thus it can be seen that the sample used in this study came from populations that were normally distributed.

Homogeneity test results using SPSS in the Box's M test table obtained Box's M value of 4.889 and statistical value of $F=1,603$ with sig. 0186 then it is accepted. This means that the $\mathrm{PjBeL}$ and direct e-learning variables have the same covariance variance matrix so Mancova analysis can proceed.

The results of the linearity test analysis obtained the value of Deviation from Linearity sig. is $0.055>$ from 0.05 and the Fcount is 1.728 $<$ Ftable 1.75. Thus $\mathrm{H}_{1}$ is accepted. The conclusion is that there is a significant linear relationship between covariates (pretest learning outcomes) with learning outcomes. Likewise for critical thinking skills the value of sig. obtained is $0.188>$ from 0.05 and $F_{\text {count }}$ is $1.329<\mathrm{F}_{\text {table }} 1.75$. Thus $\mathrm{H}_{1}$ is accepted. The conclusion is that there is a significant linear relationship between covariates (pretest critical thinking skills) with students critical thinking skills.

Collinierity test is done by calculating the correlation coefficient between learning outcome variables $\left(\mathrm{Y}_{1}\right)$ and students' critical thinking skills $\left(\mathrm{Y}_{2}\right)$. The test criteria are learning outcomes variable and critical thinking skills will experience collinear if the correlation coefficient between variables $\left(\mathrm{r}_{\mathrm{y} 1 \mathrm{y} 2}\right)>0.8$ (Candiasa, 2010). The process of calculating the collinearity test uses the product moment calculation which results in $0.00479<0.8$. So it can be collected learning outcomes variables with students' critical thinking skills do not experience correlation. So that the Mancova test can be performed on data. 
After normality test, homogeneity, linearity and data collinerity test according to criteria, the next step is testing the hypothesis using Moncova analysis. The results can show:

First; The results show that the influence of covariates (learning outcomes \& pretest critical thinking skills) and the influence of learning models, obtained the value of Multivariate Testsc sig. is $0.001<$ of 0.05 and the value of the $F_{\text {count }}$ Pretest Learning outcomes is 9,820, the value of the $\mathrm{F}_{\text {count }}$ Pretest Critical Thinking Skills is 17,262, the value of the $F_{\text {count }}$ Learning Model is 85,279. Thus there are differences in learning outcomes and critical thinking skills of students between the experimental class who are learning to use the $\mathrm{PjBeL}$ model and the control class that is learning to use the direct e-learning model.

Second; Based on the influence of the learning model on the final learning outcomes obtained value of $F_{\text {count }}=0.373$ and sig. in the amount of $0.542>0.05$. Means there is no difference in the effect of the learning model of $\mathrm{PjBeL}$ and direct e-learning on student learning outcomes. Student learning outcomes in classes PjBeL $(\mathrm{M}=15.44 ; \mathrm{SD}=2.87)$ and direct elearning classes $(\mathrm{M}=14.77$; $\mathrm{SD}=3.29)$

Third; Based on the influence of the learning model on the final critical thinking skills, the value of Fcount $=166,571$ and sig is obtained. amounted to $0.001<0.05$. It means that there are differences in the effect of the $\mathrm{PjBeL}$ model and direct e-learning on students' final critical thinking skills. Student learning outcomes in classes PjBeL $(\mathrm{M}=32.07 ; \mathrm{SD}=2.89)$ and direct e-learning classes $(\mathrm{M}=25.16 ; \mathrm{SD}=3.59)$. If viewed based on the 6 dimensions of critical thinking skills, the comparison of the results of critical thinking skills can be seen in Figure 2.

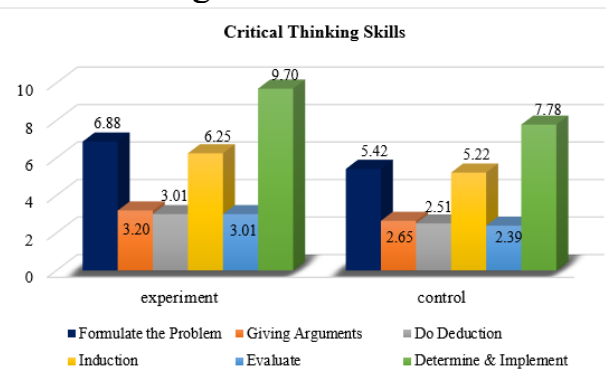

Figure 9.Comparison of Results of Students' Critical Thinking Skills Based on Dimensions.

From Figure 2 shows that the experimental class using the PjBeL learning model has an advantage in critical thinking skills compared to students who study in the control class using the direct e-learning model.

\section{DISCUSSION}

\section{The Effect of Project Based e-Learning Models (PjBeL) on Student Learning Outcomes and Critical Thinking Skills together.}

This section further discusses the research results that have been obtained. The results of the study include descriptive analysis and statistical analysis which reveal the effect of the independent variables on the dependent variable. The independent variables in this study are the $\mathrm{PjBeL}$ learning model and direct e-learning in digital simulation subjects while the dependent variable in this study is the learning outcomes and students' critical thinking skills.

After being given treatment in the experimental class the final test is given, as is the control class. Descriptive analysis of the results of the study found that the comparison of Learning Results (Pretest / Posttest) Digital Simulation Experiment and Control class has increased, which in the experimental class has increased Very High categories of $23.78 \%$ and $1.49 \%$ of students have increased in the High category, and have decreased categories Medium by $17.27 \%$ and $11.94 \%$ of students experienced a decrease in the category of Low and there were no students who had the results of learning Digital Simulation categorized Very Low. Whereas the control class experienced an increase in the Very High category by $16.16 \%$ and $4.45 \%$ of the students had an increase in the High category, and a decrease in the Medium category by $4.55 \%, 15.15 \%$ in the Low category and $1.52 \%$ of students in the Very Low category. And for the descriptive analysis of critical thinking skills, it was found that the comparison of the Critical Thinking Skills (Pretest / Posttes) of the Digital Simulation Experiment and Control class had increased, which in the experimental class experienced a Very High category increase of $67.16 \%$ and a decrease in the High category of $13.43 \%$, a category Medium of $43.26 \%$ and $10.45 \%$ of students experienced a decrease in the Low category and there were no students who had Critical Thinking Skills in Digital Simulation categorized as Very Low. Whereas in the control class there was an increase in the category of Very High by $1.51 \%$ and $34.85 \%$ of students experienced an increase in the category of High, and a decrease in the category of Medium by $25.76 \%, 10.61 \%$ in the category of Low and and there were no students who had Critical Thinking Skills in the Digital Categorization category Very Low. Thus, the results of the pre / post-test learning outcomes and students' critical thinking skills seen from the 
descriptive analysis in the experimental group were greater than the control group and both experienced an increase. For the calculation of normality, homogeneity, and t-test using SPSS 16.0 the results are not much different, where both the experimental group and the control group have normal and homogeneous data.

Based on statistical tests using SPSS, the results show that there is an influence of covariates (pretest learning outcomes \& pretest critical thinking skills) and the influence of learning models together, the value of Multivariate Testsc is obtained. is $0.001<0.05$ and the value of the Fcount Pretest Learning outcomes is 9,820, the value of the Fcount Pretest Critical Thinking Skills is 17,262 , the value of the Fcount Learning Model is 85,279. Thus $\mathrm{H}_{0}$ is rejected.

The results of this study affect the learning outcomes and critical thinking skills of class X AP in line with several studies that also have an influence on the implementation of elearning-based project-based learning models including: (1) Jamilla and Lazulva. (2020) shows that the project-based learning model assisted by google classroom provides better learning outcomes in the cognitive realm. The ability to understand the chemical concepts of students who learn with the project-based learning model assisted by google classroom using learning videos is better than the lecture learning method. (2) (Niswara et al., 2019) states that the application of the project-based learning model assisted by puzzle media has an influence on high order thingking student skills. This is evidenced from the more interactive students in the learning process and students are able to create good learning conditions and situations by using a project-based learning model assisted by puzzle media. (3) (Na'imah et al., 2015) he said from the results of his research showed the feasibility of applying e-learning-based project-based learning models to improve student learning outcomes both psychomotor, affective and cognitive assessment of students. This is evidenced from the increase in students' activeness during the learning process and increased motivation in learning.

\section{The Effect of Project Based e-Learning Models (PjBeL) on Student Learning Outcomes}

This study provides the result that the null hypothesis is accepted so that there is no difference in learning outcomes between students who learn using the project-based e-learning model and students who study with direct elearning Digital Simulation subjects in Class X of SMK Negeri 1 Sawan. When viewed from the results of descriptive analysis, the learning outcomes of Digital Simulation pretest and posttest subjects increased in the experimental class and the control class. This is in line with research conducted by (Jamilla et al., 2020), which revealed that the project-based learning model assisted by Google's classroom using instructional videos has a positive impact in the learning process, where the model must be designed in such a way according to student characteristics and material learning that will be applied during the learning process in order to improve students' ability to receive lessons and improve learning outcomes to be more effective when the learning process takes place. Likewise according to (Santyasa et al., 2020) revealed in his research that there are significant differences in academic achievement between students studying in the PjBL and DI models. Which higher academic achievement is achieved by students studying with the PjBL model. The obstacle revealed in this study is that there are significant differences in academic achievement between students who have high academic procrastination (HAP) and low academic procrastination (LAP). Higher learning achievement is achieved by students who have PAP. And the final results of this study reveal that there is an interactive effect between learning models and academic procrastination on student academic achievement. Strong interactions occur at low procrastination for both learning models. From these studies prove the learning model has an impact on both learning achievement and student procrastination itself. However, when viewed from statistical analysis, the results show that the $\mathrm{PjBeL}$ learning model has no effect on student learning outcomes in both the experimental class and the control class. This can be caused by several obstacles in the study.

First, the development of learning outcomes test instruments in this study needs to be further studied. Especially in the selection of questions that will be used as a measurement of student ability. All learning outcomes tests used in this study have IKB in the "Medium" category. and IDB which is "Enough". It is better for the test used to have IKB with varied categories (easy, medium and difficult categories) by keeping on the theory that the tests used are test items that have IKB $>0.30$ and IDB which are categorized as "Good". The instruments made in this study use objective tests, where the results obtained are definitive answers, (true and false) so students are required to really understand the material and questions provided in the research instrument to get maximum results. 
Secondly, this can also occur as a result of the lack of maximum time allocation for applying the learning model in class. This research was conducted 6 meetings in each class. According to Santyasa (2019), there are several factors that are considered to hamper the successful application of innovation in learning, namely the advantages of innovation are relatively difficult to explain and prove and are considered time and cost consuming. Therefore, for the application of innovation in electronic-based learning, it takes longer for students and teachers to adapt. So it will have a more real impact on student learning outcomes.

Third, the infrastructure owned by students in the online learning process. Most students still do not have learning facilities and infrastructure that are categorized as good. In the learning process students are constrained by connections in the learning process so that during the learning process there are some students who are still less than optimal in following the learning process at each meeting.

\section{The Effect of Project Based e-Learning Models (PjBeL) on Students' Critical Thinking Skills}

The results of statistical analysis show that the PjBeL learning model influences students' final critical thinking skills. This shows that $\mathrm{H} 0$ is rejected and $\mathrm{H}_{1}$ is accepted. Based on the results of statistical analysis conducted on 2 experimental classes and 2 control classes based on covariates (pretest critical thinking skills) on the final critical thinking skills, the value of Fcount $=27,227$ and sig was obtained. amounted to $0.001<0.05$. Mean covariate (pretest critical thinking skills) of the learning model influences students' final critical thinking skills. Whereas if we look at the six dimensions of students' critical thinking skills, it shows that the experimental class using the project-based e-learning learning model has advantages in critical thinking skills compared to students who learn in the control class using the direct e-learning model.

This finding is supported by the results of research conducted by (Marza et al., 2019) in which the findings in this study indicate that there is a positive influence on the ability to think critically and cooperate with elementary students after applying the project-based learning model. The implication is that in applying the project based learning model of learning in the learning process there is a process of interaction between students and teachers and the learning environment that aims to produce a change in behavior, changes that initially could not be able to, which previously did not know to know. So when the application of the project based learning model the teacher is able to be more interactive with students and be able to create various conditions and situations in learning both at home and in class to produce changes in accordance with the objectives, both learning outcomes and thinking abilities (cognitive, affective, and psychomotor ). Similarly, research conducted by (Permana et al., 2019) of this study revealed that there was a development of critical thinking skills and histological concepts of students from projectbased learning through blended learning. Based on this, it can be concluded that project-based learning can develop critical thinking skills and student learning concepts.

\section{CONCLUSION}

Based on the results of hypothesis testing, in this study it can be concluded that:

There are differences in learning outcomes and critical thinking skills together between students who learn to use the project based e-learning model and students who learn by direct e-learning in Digital Simulation subjects in Class X of SMK Negeri 1 Sawan. These results can be seen from the results of testing the hypothesis using Mancova analysis in which the value of Multivariate Testsc sig is obtained. is $0.001>$ of 0.05 and the value of the $\mathrm{F}_{\text {count }}$ Pretest Learning outcomes is 9,820 , the value of the $F_{\text {count }}$ Pretest Critical Thinking Skills is 17,262 , the value of the $\mathrm{F}_{\text {count }}$ Learning Model is 85,279 . Thus $\mathrm{H}_{0}$ is rejected.

There is no difference in learning outcomes between students who learn to use the project based e-learning model and students who learn by direct e-learning in Digital Simulation subjects in Class X of SMK Negeri 1 Sawan. These results can be seen from the results of testing the hypothesis using Mancova analysis in which the Multivariate Tests sig value is obtained. $0.542>0.05$ and the final learning result obtained $\mathrm{F}_{\text {count }}=0.373$. Thus $\mathrm{H}_{0}$ is accepted.

There are differences in critical thinking skills between students who learn to use the project based e-learning model and students who learn by direct e-learning in Digital Simulation subjects in Class X of SMK Negeri 1 Sawan. These results can be seen from the results of testing the hypothesis using Mancova analysis in which the value of Multivariate Testsc sig is obtained. $0.001<0.05$ and the final critical thinking skills obtained value of $F_{\text {count }}=166.571$. Thus $\mathrm{H}_{0}$ is rejected. 


\section{REFERENCES}

Barell, J. (2010). Problem based learning: The Foundation for 21st century skills. In J. Ballanca \& R. Brandt (Eds.), 21st century skills: Rethinking how students learn. Bloomington, IN: Solution Tree Press.

Candiasa, I. (2010). Statistik multivariat disertai aplikasi SPSS. Singaraja: Unit Penerbit Undiksha.

Hashemi, S. A. (2011). The Use Of Critical Thinking In Social Science Textbooks of High School: A Field Study of Fars Province in Iran. International Journal of intructional, 4(1), (2011) 63-78 (P-ISSN: 1694-609X). Tersedia pada:

https://files.eric.ed.gov/fulltext/ED522910.pd f.

Jamilla, Widia, Qholby., \& Lazulva. (2020). Pengaruh penerapan model project-based learning melaui google classroom terhadap hasil belajar siswa pada materi laju reaksi. Jurnal of Research and Education Chemistry (JREC). 2(1), (2020) 23-29 (E-ISSN: 2685-8959, PISSN: 2685-8967). Tersedia pada: https://journal.uir.ac.id/ index.php/jrec/article/view/4863.

Kemdikbud. (2013). Model pengembangan berbasis proyek (Project Based Learning). Tersedia pada: http//www.staff.uny.ac.id.

Kemendikbud. (2013). Model pembelajaran berbasis proyek (Project Based Learning). Jakarta: Kementrian Pendidikan dan Kebudayaan.

Marza, Anggara., M, Fachri., Yanti. (2019). Pengaruh model project-based learning (PjBL) terhadap kemampuan berpikir kritis dan kerjasama siswa pada pembelajaran tematik terpadu kelas iv SD. Jurnal Basicude, 3(2), (2019) 456-462, (P-ISSN: 2580-3735, E-ISSN: 25801147). Tersedia pada: https://jbasic.org/index.php /basicedu.
Na'imah, Jannatu., Supartono., \& Sri Wardani. (2015). Penerapan pembelajaran berbasis proyek berbantuan e-learning untuk meningkatkan hasil belajar siswa. Jurnal Inovasi Pendidikan Kimia, 9(2), (2015) 1566-1574. Tersedia pada: https://journal.unnes.ac.id/nju/index .php/JIPK/ article/view/4824.

Niswara, Rika., Muhajir., Mei Fita. (2019). Pengaruh model project-based learning terhadap high order thinking skill. Mimbar PGSD Uniksha, 7(2), (2019) 85-90. Tersedia pada: https://ejournal.undiksha.ac.id/index.php /JJPGSD/article/view/17493.

Permana, Fendy, Herdian., \& Lise. (2019). Project based learning through edmodo: improving critical thingking and histology concepts. Jurnal Pendidikan Biologi, 12(1), (2019) 5869. Tersedia pada: http://journal.unj .ac.id/unj/index.php/biosfer/article/ view/10544/7124.

Rahayu,S., \& Hadayat, A. (2017). Penerapan model pembelajaran problem-based learning (PBL) terhadap kemampuan berpikir kritis siswa kelas X IPA SMAN 1 Sukawangi pada materi pencemaran lingkungan. Jurnal skripsi pendidikan Biologi. (2017) 1-8. Tersedia pada: http://digilib.uinsgd.ac.id/ 4116/1/Jurnal\%20Siti\%20Rahayu\% 20pdf.pdf. Diakses pada 13 Juni 2020.

Santyasa, I. W. (2019). Metodologi penelitian pendidikan. Singaraja: Undiksha Press.

Santyasa, I W., Rapi, N. K., \& Sara, I M. M. (2020). Project based learning and academic procrastion of students in learning physics. International Journal of instruction. 13(1), (2020) 489-508 (P-ISSN: 1694-609X). Tersedia pada: http://eiji.net/dosyalar/iji $2020 \quad 1$ 32.pdf.

Yani \& Ruhimat. (2018). Teori dan Implementasi Pembelajaran Saintifik Kurikulum 2013. Bandung: PT Refika Aditama. 